\title{
ROUTINE PLACEMENT OF DRAIN IN THYROID SURGERY: IS THERE ANY SCIENTIFIC BASIS?
}

\author{
Srikanth Kulkarni', Rajesh B. M², Ramachandra M³, Sathish Chandra M. R4, Dileep Ramesh Hoysal5
}

${ }^{1}$ Associate Professor, Department of Surgery, BGS Global Institute of Medical Sciences, Bangalore.

${ }^{2}$ Assistant Professor, Department of Surgery, BGS Global Institute of Medical Sciences, Bangalore.

3 Professor, Department of Surgery, BGS Global Institute of Medical Sciences, Bangalore.

${ }^{4}$ Assistant Professor, Department of Community Medicine, BGS Global Institute of Medical Sciences, Bangalore.

${ }^{5}$ Assistant Professor, Department of Surgery, BGS Global Institute of Medical Sciences, Bangalore.

\section{ABSTRACT}

\section{OBJECTIVE}

To determine the efficacy of routine placement of drain after Thyroid surgery.

To compare patients undergoing thyroid surgery without placement of suction drain versus patients undergoing surgery with placement of suction drain.

\section{METHODOLOGY}

This is a Single Surgeon's Clinical study over a period of 8 years in 2 teaching hospitals; 112 patients undergoing thyroid surgeries for various diagnoses from July 2007 to August 2015 were studied retrospectively. Variables taken into account were duration of hospital stay, postoperative pain and postoperative complications.

\section{RESULTS}

The study included 112 patients undergoing thyroid surgeries being grouped into two groups. The length of the hospital stay was reduced in the no drain group. Mean duration of hospital stay was 5+/-1.78 days in drain group and 2+/-0.72 in no drain group But no significant difference was found between the groups in the postoperative complications like haematoma and seroma formation.

\section{CONCLUSION}

Drains should be used only in selected cases of Thyroid surgeries. Drainless thyroidectomy causes less discomfort, short hospital stay and does not increase the risk of postoperative complications.

\section{KEYWORDS}

Thyroid, Drain, Postoperative complications.

HOW TO CITE THIS ARTICLE: Kulkarni S, Rajesh BM, Ramachandra M, et al. Routine placement of drain in thyroid surgery: is there any scientific basis? J. Evolution Med. Dent. Sci. 2016;5(23):1218-1220, DOI: 10.14260/jemds/2016/284

\section{INTRODUCTION}

Most surgeons insert drain following thyroid surgery to obliterate the dead space and to evacuate collected blood and serum. Haemorrhage can be life threatening, thus necessitating an immediate reoperation. This fear prompts surgeons to use a routine drain after any type of thyroid surgery. However, the use of drains is still controversial. ${ }^{1}$ Many studies have proved that the drains are ineffective in preventing a life-threatening haematoma formation as the small lumen of the drain usually gets blocked by clot in presence of severe bleeding.2,3 Furthermore, the drains can cause discomfort to patients. ${ }^{4}$ Our study compares the two groups in terms of hospital stay and postoperative complication like haematoma, seroma and wound infection. This is an observational study over a period of 8 years in the surgical department in Mysore Medical College.

Financial or Other, Competing Interest: None.

Submission 29-01-2016, Peer Review 01-03-2016,

Acceptance 07-03-2016, Published 18-03-2016.

Corresponding Author:

Dr. Srikanth Kulkarni

H No: 29, $4^{\text {th }}$ Main,

Sarwabowmanagar,

Chikallasandra,

Bangalore-560061.

E-mail:drsrikulk@yahoo.co.in

DOI: 10.14260/jemds/2016/284

\section{METHODOLOGY}

Mysore from July 2007 to June 2012 and BGS Global Institute of Medical Sciences, Bangalore, from November 2012 to August 2015.

All the patients who underwent thyroid surgery during this period were included in the study. They were grouped into 2 groups, one with drain and the other group without drain.

Data regarding the indications of surgery, procedures performed, local complications (Infection, haematoma, seroma, RLN palsy and hypoparathyroidism), length of the hospital stay were recorded. The surgeries included in our study were hemithyroidectomy, Dunhill's procedure, subtotal, near total and total thyroidectomy (with and without neck dissection).

\section{The Indications for placement of drain were}

- Extensive dead space.

- Excessive tissue Manipulation.

- Dissection on a highly vascular thyroid gland.

The hospital stay and postoperative complications were compared between the two groups.

\section{RESULTS}

Total number of cases included was 112. Male patients were $16(14.28 \%)$ and female patients were 96 (85.71\%). Age wise distribution is shown in Table 1 . 


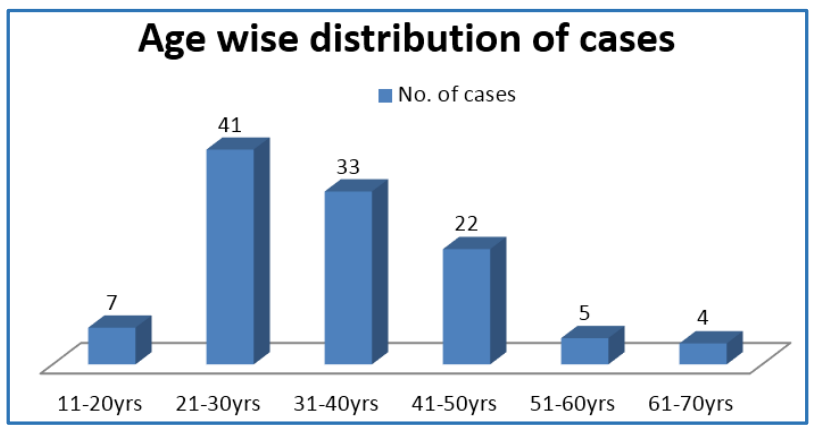

\begin{tabular}{|c|c|c|}
\hline Age in Years & No. of Cases & Percentage \\
\hline $11-20$ & 7 & $6.25 \%$ \\
\hline $21-30$ & 41 & $36.6 \%$ \\
\hline $31-40$ & 33 & $29.46 \%$ \\
\hline $41-50$ & 22 & $19.64 \%$ \\
\hline $51-60$ & 5 & $4.46 \%$ \\
\hline $61-70$ & 4 & $3.57 \%$ \\
\hline Total & 112 & 100 \\
\hline \multicolumn{2}{|c|}{ Table 1: Age wise Distribution of Cases } \\
\hline
\end{tabular}

Fig. 1: Age wise Distribution of Cases

\begin{tabular}{|c|c|c|c|c|c|c|}
\hline Diagnosis & $\begin{array}{c}\text { Right Lobe } \\
\text { Involvement }\end{array}$ & $\begin{array}{c}\text { Left Lobe } \\
\text { Involvement }\end{array}$ & Isthmus & Both Lobes & Total & Percentage \\
\hline SNT & 28 & 24 & 3 & & 55 & $49.2 \%$ \\
\hline MNG & 14 & 10 & & 12 & 36 & $32.14 \%$ \\
\hline Malignant & & & & 19 & $16.9 \%$ \\
\hline Papillary & Table 2: List of the Thyroid Conditions Diagnosed in these 112 patients \\
\hline Follicular & \multicolumn{2}{|l}{} \\
\hline \multicolumn{7}{|l}{} \\
\hline
\end{tabular}

The various diagnoses for these 112 patients are shown in Table 2.

\begin{tabular}{|c|c|c|}
\hline With Drain & 30 & $26.78 \%$ \\
\hline Without Drain & 82 & $73.21 \%$ \\
\hline Total & $\mathbf{1 1 2}$ & $\mathbf{1 0 0}$ \\
\hline Table 3: Out of these 112 patients, $30(\mathbf{2 6 . 7 8} \%)$ \\
patients had drain placement and \\
82 (73.21\%) had no drains \\
\hline
\end{tabular}

\begin{tabular}{|c|c|c|c|}
\hline Type of Surgery & $\begin{array}{l}\text { No. of } \\
\text { Cases }\end{array}$ & $\begin{array}{l}\text { Drain } \\
\text { Placed }\end{array}$ & Percentage \\
\hline Hemithyroidectomy & 67 & 14 & $20.8 \%$ \\
\hline Dunhill's procedure & 9 & 2 & $22.2 \%$ \\
\hline $\begin{array}{c}\text { Subtotal } \\
\text { thyroidectomy }\end{array}$ & 3 & 0 & $0 \%$ \\
\hline $\begin{array}{c}\text { Near total } \\
\text { thyroidectomy }\end{array}$ & 7 & 1 & $14.2 \%$ \\
\hline \multicolumn{4}{|l|}{ Total thyroidectomy } \\
\hline Alone & 10 & 3 & $30 \%$ \\
\hline With MRND & 2 & 2 & $100 \%$ \\
\hline With FND & 14 & 8 & $57.14 \%$ \\
\hline Total & 112 & 30 & \\
\hline \multicolumn{4}{|c|}{ Table 4: Requirement of Drain for Various Surgeries } \\
\hline
\end{tabular}

Out of these 30 patients who had the drain, the different types of surgeries for which the drain was placed is shown in Table 4.

\begin{tabular}{|c|c|c|c|c|}
\hline Group & $\begin{array}{c}\text { Range } \\
\text { (Days) }\end{array}$ & $\begin{array}{c}\text { Mean } \\
\text { Duration }\end{array}$ & $\begin{array}{c}\text { t } \\
\text { value }\end{array}$ & $\begin{array}{c}\text { P- } \\
\text { value }\end{array}$ \\
\hline With drain & $2-8$ & $5+/-1.78$ & \multirow{2}{*}{12.74} & $<$ \\
\cline { 1 - 3 } $\begin{array}{c}\text { Without } \\
\text { drain }\end{array}$ & $1-3$ & $2+/-0.72$ & 0.0001 \\
\hline \multicolumn{4}{|c|}{ Table 5: Duration of Hospital Stay } \\
\hline
\end{tabular}

Mean duration of hospital stay was $5+/-1.78$ days in the drain group (Range of 2-8 days) and 2+/-0.72 days in the nondrain group (Range 1-3 days), which was statistically significant ( $t$ 12.74; P-value <0.0001) suggesting the reduced hospital stay among the no drain group compared with the drain group (Table 5).

\begin{tabular}{|c|c|c|c|c|c|}
\hline $\begin{array}{c}\text { Sl. } \\
\text { No. }\end{array}$ & $\begin{array}{c}\text { Postop } \\
\text { Complications }\end{array}$ & $\begin{array}{c}\text { Drain } \\
\text { Group } \\
\mathbf{( \% )} \\
(\mathbf{n = 3 0 )}\end{array}$ & $\begin{array}{c}\text { No- } \\
\text { Drain } \\
\text { Group } \\
\mathbf{( \% )} \\
(\mathbf{n = 8 2})\end{array}$ & $\begin{array}{c}\text { Z- } \\
\text { test }\end{array}$ & $\begin{array}{c}\text { P- } \\
\text { value }\end{array}$ \\
\hline 1 & Haematoma & $2(6.66)$ & $2(2.43)$ & & \multirow{2}{*}{0.055} \\
\hline 2 & Seroma & $2(6.66)$ & $3(3.65)$ & \multirow{2}{*}{1.92} & \\
\hline 3 & $\begin{array}{c}\text { Transient RLN } \\
\text { palsy }\end{array}$ & 0 & $1(1.22)$ & & \\
\hline 4 & Wound infection & $2(6.66)$ & 0 & & \\
\hline \multicolumn{7}{|c|}{ Table 6: Postoperative Complications } \\
\hline
\end{tabular}

The postoperative complications observed were as follows, haematoma was seen in 2 patients in drain group $(6.66 \%)$ and 2 patients in no-drain group $(2.43 \%)$. Seroma was observed in 2 patients in drain group (6.66\%) and 3 patients in no-drain group (3.65\%). Transient RLN palsy was not seen in drain group and 1 patient in no-drain group (1.22\%), who recovered completely in 4 weeks. Permanent RLN palsy was not seen in any patient in either of the groups. Wound infection was seen in 2 patients in drain group (6.66\%) and none in the no-drain group. However, there was no statistically significant (Z 1.92; P-value 0.055) difference in the postoperative complications between the groups (Table 6).

\section{DISCUSSION}

It is a common practice to place drains in thyroid surgery to prevent any collection in the operative field. ${ }^{2}$ Haemorrhage in the dead space around trachea can cause potentially lifethreatening airway compression and requires urgent reexploration. ${ }^{1}$ Haemorrhage usually occurs between 2 and 6 hours of surgery.5,6 Studies have shown that drains are ineffective in preventing blood collection because they often get blocked by clotted blood.2,3

The presence of drain is known to incite inflammatory reaction, which may lead to increased fluid production. Moreover, suction drain due to negative pressure may also prevent the cut lymphatics from closing and hence increase the fluid drainage. ${ }^{3,5}$ 
In the initial period of 2 years of our study, thyroid surgeries with drain placement were more and as experience was gained in attaining a good haemostasis the drain placement became infrequent.

The postoperative complications like Haematoma, Seroma and Wound infection revealed an obvious difference, but had no significance on statistical tests. This is comparable to other studies. ${ }^{3}$ as shown in Table 7. Postoperative pain was also significantly less in no-drain group.

\begin{tabular}{|c|c|c|c|}
\hline $\begin{array}{l}\text { Postoperative } \\
\text { Complications }\end{array}$ & $\begin{array}{c}\text { Hurtado } \\
\text { et al. } \\
\mathbf{n}=\mathbf{5 0}\end{array}$ & $\begin{array}{c}\text { Khanna } \\
\text { et al. } \\
n=51\end{array}$ & $\begin{array}{c}\text { Our } \\
\text { Study } \\
\mathbf{n}=\mathbf{8 2}\end{array}$ \\
\hline Haematoma/seroma & 2 & 3 & 5 \\
\hline Infection & 0 & 1 & 0 \\
\hline Total & 2 & 4 & 5 \\
\hline $\begin{array}{r}\text { Table 7: } \\
\text { signific }\end{array}$ & $\begin{array}{l}\text { perativ } \\
\text { ess in } 1\end{array}$ & $\begin{array}{l}\text { was als } \\
\text { in group }\end{array}$ & \\
\hline
\end{tabular}

$\mathrm{n}=$ No. of cases without drain.

The duration of hospital stay was found less in the patients without drain and the same findings are also reported by other studies. ${ }^{3,4}$ Short hospital stay lessens the burden on Hospitals, also economical for our patients as majority of them are from underprivileged group.

To summarise, the drains are not required in most of the cases of thyroidectomy. Drains can cause discomfort, increase wound infection rates and prolong hospital stay. In selected cases, placement of drain may be useful, like patients with recurrent goiter, substernal goiter and patients on anticoagulants. ${ }^{7-9}$

\section{CONCLUSION}

Thyroidectomy without drain causes less discomfort, short hospital stay and does not increase the risk of postoperative complications. Meticulous haemostasis and attention to finer details during surgery are more important for achieving this goal. Hence, routine use of drains for thyroid surgery may not be necessary. It should be reserved for selected cases of thyroidectomies.

\section{REFERENCES}

1. Colak T, Akca T, Turkmenoglu O, et al. Drainage after total thyroidectomy or lobectomy for benign thyroidal disorders. J Zhejiang Univ Sci B 2008;9:319-23.

2. Prichard RS, Murphy R, Lowry A, et al. The routine use of post operative drains in thyroid surgery: an outdated concept. Ir Med J 2010;103:26-7.

3. Khanna J, Mohil RS, Chintamani, et al. Is the routine drainage after surgery for thyroid necessary?- a prospective randomized clinical study (ISRCTN63623153). BMC Surg 2005;11.

4. Neary PM, Connor OJ, Shafiq A, et al. The impact of routine open non suction drainage on fluid accumulation after thyroid surgery: a prospective randomised clinical trial. World J Surg Oncol 2012;10:72.

5. Deveci U, Altintoprak F, Sertan Kapakli M, et al. Is the use of a drain for thyroid surgery realistic? a prospective randomized interventional study. J Thyroid Res 2013;Article Id 285768.

6. Kalemera Ssenyondo E, Fualal J, Jombwe J, et al. To drain or not to drain after thyroid surgery: a randomized controlled trial at a tertiary hospital in East Africa. AFR Health Sci 2013;13(3):748-55.

7. Musa AA, Agboola OJ, Banjo AA, et al. The use of drains in thyroid surgery. Niger Postgrad Med J 2010;17(1):15-8.

8. Memon ZA, Ahmed G, Khan SR, et al. Postoperative use of drain in thyroid lobectomy-a randomized clinical trial conducted at civil hospital, Karachi, Pakistan. Thyroid Res 2012;5:9.

9. Yasin G, Anwar MR, Awan WS, et al. Near total thyroidectomy: role of drain. Professional Med J 2014;21(2):382-5. 